\title{
A Comprehensive Strategic Analysis of the Environmental Scanning of Iranian Public Hospitals: A Prospective Approach
}

Kimia pourmohammadi

Shiraz University of Medical Sciences

Peivand Bastani

Shiraz University of Medical Sciences

Payam Shojaei

Shiraz University

nahid hatam ( $\nabla$ hatamn@sums.ac.ir)

Asiyeh Salehi

Southern Cross University

\section{Research note}

Keywords: public hospital, environmental scanning, strategic management, PESTLE analysis, future, Iran

Posted Date: December 4th, 2019

DOI: https://doi.org/10.21203/rs.2.18281/v1

License: (1) This work is licensed under a Creative Commons Attribution 4.0 International License.

Read Full License

Version of Record: A version of this preprint was published at BMC Research Notes on March 26th, 2020. See the published version at https://doi.org/10.1186/s13104-020-05002-8. 


\section{Abstract}

Objectives: This mixed-method study was conducted to interpret the political, economic, social and technological issues that encourage hospital managers to be aware of the conditions and be equipped to plan and perform proactively. Results: structured interview using Douglas West framework and a researcher-made questionnaire were used to determine the effectiveness and feasibility of hospitals' environmental factors. The key issues at micro level environment of public hospitals were related to prescription and overuse of pharmaceuticals, inequality in distribution of healthcare services and high demands for luxurious services. At macro level: higher fertility rates, hospital services tariffs, changes in the patterns of diseases and inappropriate hospital budgeting have direct impact and economic sanctions, government corruption, centralization and high bank interest rates have indirect impact on public hospitals in Iran. Generally the strategic policies are required to improve quality-based payment system, enhance the efficiency and effectiveness of services, improving fair income generation and urging positive motivations for service providers are the strategies to cope with the future changes. Key words: public hospital, environmental scanning, strategic management, PESTLE analysis, future, Iran

\section{Introduction}

Nowadays, organizations' environments are changing at an unprecedented rate (1). Lack of awareness of the environmental change, can result in severe consequences and complications (2). These extensive rapid changes of the modern world have a substantial effect on the health systems $(3,4)$. Healthcare systems are considered as the largest economic sectors in the world, and have a major role in social development and welfare. Among this, hospitals play a key role in the fair promotion of healthcare and improvement of the fairness index in healthcare (5-7). At the same time, they are the most fundamental and expensive components of the health system, in as much as they account for $40 \%$ and $80 \%$ of total health sector expenses in developed and developing countries, respectively (8-11).

Environmental changes have resulted in political, economic, social, cultural, and technological changes for hospitals on a large scale. Population aging, health technological advances, information technology developments, and remote medical systems are among such changes affecting healthcare systems (12). To assure the sustainability and attainment of goals, health organizations need to rapidly adopt to and interact with external and internal environments to respond to such changes, otherwise, they may be doomed to failure $(2,13)$.

To this end, environmental scanning acts as a radar used for identifying environmental signals and an effective way for organizations to prevent uncertainty and develop compatible strategies (14). Environmental scanning is a strategic process, mostly used in complicated environments with high levels of uncertainty (15). The aim of environmental scanning is to predict and comprehend internal and external organizational events and relations in order to decrease uncertainty $(16,17)$. By using this method, organizations could obtain information on threats and opportunities that potentially affect performance or jeopardize the organizational sustainability or performance (13). Therefore, the 
organizations that perform effective environmental scanning activities have higher chances of thwarting threats and understanding opportunities and thus gain sustainable competitive advantages (14).

The organization environment consists of external and internal components. The external environment, including micro and macro environments is related to factors outside the normal borders of the organization affecting management decisions (18). The macro environment includes factors with indirect long-term political, economic, social, cultural, technological, and legal impacts. While, the micro environment refers to factors that directly affect organizational functions and outcomes, such as customers, suppliers/resources, competition, and other stakeholders. $(14,18)$. Considering the significance and need to identify factors and environmental changes affecting organizational performance (1), this study scanned the environments of Iranian public hospitals to provide recommendations for enhancing the hospital management for achieving quality and at the same time, cost-efficient services.

\section{Main Text}

Methods

Study design

This mixed-method study was conducted in 2017-18 in two phases:

Phase 1: Analyzing environmental factors affecting Iranian public hospitals

In this phase, the environments of Iranian public hospitals were analyzed using the framework proposed by Douglas West et al. (18)

For this purpose, a structured in-depth interviews were conducted among a panel of experts from diverse ranges of disciplines in healthcare to achieve a holistic and comprehensive understanding of the issues. Purposive snowball sampling was used for the selection of participants.

Participants were informed about the research purpose. The initial sample size was estimated to be 12 experts. Considering possible withdrawal, 16 experts were selected. Individual interviews with 16 experts were saturated.

The questions were formed according to the framework proposed by West et al (2015). Four 90-minute panel meetings were held to finalize interview analyses. The participant consent was obtained to record and take notes of all interviews and panel meetings. Recorded files transcribed, and shared with the participants for verification and possible feedback.

Data analysis was performed using the deductive method, including familiarization, identifying a thematic framework, indexing, charting, and mapping and interpretation (19). MAXQDA-11 was used for 
data analysis. The final expert panel meeting was held and corrections were made in accordance to their views to reach an agreement on the extracted factors and their relevance to research purposes.

Phase 2: Determining the impact and uncertainty of environmental factors affecting Iranian hospitals

In the second stage, the study analyzed the impact and uncertainty of each factor in Iran's public hospitals based on results of first phase. At this stage, a research-made questionnaire based on first stage was used to determine the level of impact and uncertainty. The 5-point Likert scale was used for this purpose. First, the experts were asked (via phone) for the permission to contact them to complete the questionnaires, which were then sent electronically. Average views of the participants on every question were determined to analyze. The data were analyzed by descriptive statistics using Microsoft Excel 2013 software.

\section{Results}

\section{Micro environment}

The key effective factors of the micro environment were categorized as consumers (socio-demographic characteristics, income, education, and health literacy of consumers, inclinations to use luxurious services, demands for receiving high-quality services and demanding modern technologies), distributors (unfair bed, staff and pharmaceutical distribution), stakeholders (internal "clinical and nonclinical staff, faculty member, medical and nonmedical students, patients, carers and family members" and External "insurance organizations, ministry of health and medical education, physicians, professional organization and nursing professional organization") and competitors (home care and nursing care services and also the smart intervention). Furthermore, the impacts of these factors on public hospitals were identified along with their types and strengths. Table 1 indicates further details. 
Table 1

Environmental Impact Matrix (micro environment)

\begin{tabular}{|c|c|c|c|}
\hline Dimensions & Factors & Impact of Factors & $\begin{array}{l}\text { Potential } \\
\text { Opportunities/Threats }\end{array}$ \\
\hline \multirow[t]{8}{*}{$\begin{array}{l}\text { Customer, } \\
\text { public and } \\
\text { media }\end{array}$} & $\begin{array}{l}\text { More inclination } \\
\text { towards using } \\
\text { luxurious health } \\
\text { services }\end{array}$ & $\begin{array}{l}\text { Increased costs, higher quality } \\
\text { services, overuse of complicated } \\
\text { expensive technologies }\end{array}$ & -3 \\
\hline & $\begin{array}{l}\text { More demand for } \\
\text { high quality health } \\
\text { services }\end{array}$ & $\begin{array}{l}\text { Higher costs, human resources, } \\
\text { expensive equipment }\end{array}$ & -2 \\
\hline & $\begin{array}{l}\text { Increase in average } \\
\text { income }\end{array}$ & Increase in hospital income & +5 \\
\hline & $\begin{array}{l}\text { Increase in } \\
\text { purchasing power }\end{array}$ & Increase in hospital income & +5 \\
\hline & $\begin{array}{l}\text { Education level and } \\
\text { health literacy } \\
\text { improvement }\end{array}$ & $\begin{array}{l}\text { Decrease in hospitalization period } \\
\text { and increase of bed turnover rate }\end{array}$ & +3 \\
\hline & $\begin{array}{l}\text { Organic and green } \\
\text { products attitude }\end{array}$ & $\begin{array}{l}\text { Decrease in diseases and demand } \\
\text { for health services which will lead } \\
\text { to quality improvement in public } \\
\text { hospitals }\end{array}$ & +3 \\
\hline & $\begin{array}{l}\text { Environment } \\
\text { protection and } \\
\text { green energy use } \\
\text { attitude }\end{array}$ & $\begin{array}{l}\text { Increase in hospital expenses for } \\
\text { healthy waste disposal and use of } \\
\text { latest technologies with green } \\
\text { energy }\end{array}$ & +1 \\
\hline & $\begin{array}{l}\text { Increase in people's } \\
\text { share in health } \\
\text { services payments }\end{array}$ & Increase in hospital specific income & +3 \\
\hline \multirow[t]{2}{*}{ Distributors } & $\begin{array}{l}\text { Unfair bed } \\
\text { distribution }\end{array}$ & $\begin{array}{l}\text { Longer patient wait times leading to } \\
\text { disorder and lower quality of } \\
\text { services }\end{array}$ & -4 \\
\hline & $\begin{array}{l}\text { Unfair specialized } \\
\text { human resources } \\
\text { distribution }\end{array}$ & $\begin{array}{l}\text { Longer patient wait times and non- } \\
\text { responsiveness }\end{array}$ & -5 \\
\hline \multirow[t]{2}{*}{ Suppliers } & $\begin{array}{l}\text { Increase in } \\
\text { prescription of } \\
\text { drugs out of Iranian } \\
\text { official list of drugs }\end{array}$ & $\begin{array}{l}\text { Inability to supply drugs and lower } \\
\text { quality of services }\end{array}$ & -2 \\
\hline & $\begin{array}{l}\text { Increase in the } \\
\text { number of } \\
\text { prescriptions } \\
\text { containing } \\
\text { antibiotics }\end{array}$ & $\begin{array}{l}\text { Patients' resistance to treatment } \\
\text { and higher doses of drugs leading } \\
\text { to medicine supply issues }\end{array}$ & -2 \\
\hline
\end{tabular}




\begin{tabular}{|c|c|c|c|}
\hline Dimensions & Factors & Impact of Factors & $\begin{array}{l}\text { Potential } \\
\text { Opportunities/Threats }\end{array}$ \\
\hline
\end{tabular}

\begin{tabular}{|c|c|c|c|}
\hline & $\begin{array}{l}\text { Increase in the } \\
\text { number of } \\
\text { prescriptions } \\
\text { containing } \\
\text { injections }\end{array}$ & $\begin{array}{l}\text { Patients' resistance to treatment } \\
\text { and higher doses of drugs leading } \\
\text { to medicine supply issues } \\
\text { Increase in design costs and } \\
\text { equipping hospitals with clean } \\
\text { rooms }\end{array}$ & -2 \\
\hline & $\begin{array}{l}\text { Increase in the } \\
\text { number of self- } \\
\text { medication cases in } \\
\text { patients }\end{array}$ & $\begin{array}{l}\text { Increase in the number of patients } \\
\text { with no appointments leading to } \\
\text { longer patient wait times }\end{array}$ & -3 \\
\hline \multirow[t]{3}{*}{ Stakeholders } & $\begin{array}{l}\text { Delayed payment to } \\
\text { hospitals by } \\
\text { insurance } \\
\text { companies }\end{array}$ & $\begin{array}{l}\text { Hospitals being indebted and } \\
\text { therefore unable to supply medicine } \\
\text { and consumer products or } \\
\text { purchasing low quality products } \\
\text { that in turn will lead to patient } \\
\text { dissatisfaction. In addition, delay in } \\
\text { personnel reimbursement can result } \\
\text { in lack of satisfaction and } \\
\text { motivation to provide high quality } \\
\text { care. }\end{array}$ & -5 \\
\hline & $\begin{array}{l}\text { Full-time status of } \\
\text { clinical faculty } \\
\text { members (non- } \\
\text { permissibility of } \\
\text { simultaneous work } \\
\text { in both public and } \\
\text { private sectors) }\end{array}$ & $\begin{array}{l}\text { Shorter patient wait times and more } \\
\text { responsiveness }\end{array}$ & +4 \\
\hline & $\begin{array}{l}\text { Freedom of speech } \\
\text { in media, } \\
\text { multiplicity of } \\
\text { political parties, civil } \\
\text { rights, meetings or } \\
\text { campaigns to } \\
\text { support or ban } \\
\text { health policies } \\
\text { (social - political) }\end{array}$ & $\begin{array}{l}\text { Compromised reputation of public } \\
\text { hospitals due to myriad economic } \\
\text { and political issues }\end{array}$ & -2 \\
\hline \multirow[t]{3}{*}{ Competitors } & $\begin{array}{l}\text { More inclination } \\
\text { towards receiving } \\
\text { home care and } \\
\text { nursing care }\end{array}$ & $\begin{array}{l}\text { Shorter wait times and improved } \\
\text { quality of services and } \\
\text { opportunities for launching home } \\
\text { care }\end{array}$ & +3 \\
\hline & $\begin{array}{l}\text { Growth in usage of } \\
\text { health promotion } \\
\text { software }\end{array}$ & $\begin{array}{l}\text { Decreased rate of referring to } \\
\text { hospitals and shorter wait times }\end{array}$ & +2 \\
\hline & $\begin{array}{l}\text { Growth of clinics } \\
\text { and private } \\
\text { hospitals }\end{array}$ & $\begin{array}{l}\text { Shorter wait times in public } \\
\text { hospitals and improved quality of } \\
\text { services }\end{array}$ & +5 \\
\hline
\end{tabular}




\begin{tabular}{|c|c|c|c|}
\hline Dimensions & Factors & Impact of Factors & $\begin{array}{l}\text { Potential } \\
\text { Opportunities/Threats }\end{array}$ \\
\hline & $\begin{array}{l}\text { Important basic } \\
\text { infrastructures } \\
\text { (facilities and } \\
\text { installations) in Iran } \\
\text { and the city in } \\
\text { which the hospital } \\
\text { is located }\end{array}$ & $\begin{array}{l}\text { Remote medical services and } \\
\text { electronic medical record option }\end{array}$ & +5 \\
\hline & $\begin{array}{l}\text { Good academic and } \\
\text { knowledge } \\
\text { developments in } \\
\text { Iran and the city in } \\
\text { which the hospital } \\
\text { is located }\end{array}$ & $\begin{array}{l}\text { Improved treatment processes and } \\
\text { quality of services and patient } \\
\text { satisfaction }\end{array}$ & +3 \\
\hline & $\begin{array}{l}\text { A chance to make } \\
\text { the required } \\
\text { investments for } \\
\text { research and } \\
\text { development in Iran }\end{array}$ & $\begin{array}{l}\text { Improved treatment processes and } \\
\text { quality of services and patient } \\
\text { satisfaction }\end{array}$ & +4 \\
\hline & $\begin{array}{l}\text { Good developments } \\
\text { in high-end } \\
\text { technologies in } \\
\text { hospitals }\end{array}$ & $\begin{array}{l}\text { Improved treatment processes and } \\
\text { quality of services and patient } \\
\text { satisfaction }\end{array}$ & +3 \\
\hline & $\begin{array}{l}\text { Availability of high- } \\
\text { end technologies in } \\
\text { the relative industry } \\
\text { of hospitals }\end{array}$ & Higher hospital expenses & -2 \\
\hline & $\begin{array}{l}\text { Available required } \\
\text { communication } \\
\text { structures } \\
\text { Good developments } \\
\text { in information and } \\
\text { communication } \\
\text { technology }\end{array}$ & $\begin{array}{l}\text { Remote medical services and } \\
\text { electronic medical record option }\end{array}$ & +5 \\
\hline & $\begin{array}{l}\text { Electronic } \\
\text { commerce option } \\
\text { for hospitals }\end{array}$ & $\begin{array}{l}\text { Income generation } \\
\text { Growth of medical tourism industry }\end{array}$ & +4 \\
\hline & $\begin{array}{l}\text { Using social media } \\
\text { to promote hospital } \\
\text { products }\end{array}$ & Income generation & +4 \\
\hline
\end{tabular}

Table 1.

Macro environment 
Based on PESTLE framework, macro factors were explored and the effectiveness and certainty of the factors were also analyzed. Macro factors were classified as political, economic, social, technological, legal, and environmental dimensions (Table 2). 
Table 2

Environmental Impact and Certainty (Macro Environment- PESTLE Analysis)

\begin{tabular}{|c|c|c|c|}
\hline Aspects & Factors & Influence & Certainty \\
\hline \multirow[t]{17}{*}{ Economic } & $\begin{array}{l}\text { Improved payment system structure (strategic services } \\
\text { purchase by insurance companies based on quality and } \\
\text { price) }\end{array}$ & +5 & +3 \\
\hline & Improved tariff structures & +4 & +2 \\
\hline & $\begin{array}{l}\text { Improved drugs and consumption products purchase } \\
\text { control structure }\end{array}$ & +5 & +3 \\
\hline & Higher inflation in the health sector & -5 & -5 \\
\hline & Higher expenses (drugs and treatment) & -5 & -5 \\
\hline & Higher inflation & -4 & -5 \\
\hline & Higher bank interest rates & -4 & -4 \\
\hline & Improved financing structure & +5 & +3 \\
\hline & $\begin{array}{l}\text { Currency rate fluctuations and multiplicity of currency } \\
\text { rates }\end{array}$ & -4 & -5 \\
\hline & Supportive role of government financial policies & +5 & +2 \\
\hline & $\begin{array}{l}\text { Providing access to capital/loans to develop hospitals' } \\
\text { activities by the government }\end{array}$ & +4 & +4 \\
\hline & Good market economic growth & +3 & +1 \\
\hline & $\begin{array}{l}\text { Availability of required finances (from public government } \\
\text { budget, charities, etc.) to produce hospitals products and } \\
\text { services }\end{array}$ & +5 & +2 \\
\hline & Smaller budget share for the health sector & -5 & -5 \\
\hline & $\begin{array}{l}\text { Approved national Iranian pharmacopoeia and the } \\
\text { comprehensive list of equipment }\end{array}$ & +3 & +3 \\
\hline & $\begin{array}{l}\text { More budget limitations for the health sector as a result of } \\
\text { economic and health load of non-communicable and } \\
\text { emerging diseases because of environmental changes }\end{array}$ & -3 & -3 \\
\hline & Economic sanctions & -3 & -5 \\
\hline \multirow[t]{4}{*}{ Political } & Regional competitions & -1 & -3 \\
\hline & Policy makers' neglect of the health sector & -4 & -3 \\
\hline & Centralization in the dominant attitude & -4 & -5 \\
\hline & Government budget-cutting structure & -5 & -5 \\
\hline
\end{tabular}




\begin{tabular}{|c|c|c|c|}
\hline Aspects & Factors & Influence & Certainty \\
\hline & Implementation of the Family Physician Program & +2 & +3 \\
\hline & $\begin{array}{l}\text { Periodic changes of politicians leading to change of plans } \\
\text { of directors (political instability) }\end{array}$ & -3 & -5 \\
\hline & $\begin{array}{l}\text { Lack of appropriate philosophy and viewpoint about } \\
\text { health and its various dimensions among political parties } \\
\text { and formations }\end{array}$ & -3 & -4 \\
\hline & $\begin{array}{l}\text { Government downsizing based on various laws, including } \\
\text { the 44th principle (privatization development) }\end{array}$ & +4 & +3 \\
\hline & Government financial corruption & -4 & -4 \\
\hline & $\begin{array}{l}\text { Unreasonable tariffs determined for hospitals products } \\
\text { and services }\end{array}$ & -5 & -5 \\
\hline & Political sanctions & -4 & -5 \\
\hline \multirow{9}{*}{$\begin{array}{l}\text { Social and } \\
\text { cultural }\end{array}$} & Higher population growth & -3 & -5 \\
\hline & Higher fertility rates & -3 & -4 \\
\hline & Change of diseases load towards chronic illnesses & -5 & -5 \\
\hline & Lower physical activity & -3 & -4 \\
\hline & Higher life expectancy & -3 & -4 \\
\hline & Higher poverty & -4 & -5 \\
\hline & $\begin{array}{l}\text { Appropriate population distribution (young human } \\
\text { resources to total population ratio) }\end{array}$ & +2 & +4 \\
\hline & Appropriate family size and structure & +2 & +3 \\
\hline & $\begin{array}{l}\text { Higher rates of social harms and anomalies, including } \\
\text { divorce, crimes, and violence. }\end{array}$ & -3 & -4 \\
\hline Technology & $\begin{array}{l}\text { Improved health information technology (home care, } \\
\text { remote medical services, remote training, electronic } \\
\text { medical record) }\end{array}$ & +4 & +2 \\
\hline \multirow[t]{4}{*}{ Environmental } & $\begin{array}{l}\text { Higher risks and diseases resulting from environment } \\
\text { pollution }\end{array}$ & -3 & -4 \\
\hline & $\begin{array}{l}\text { Higher air pollution in cities in which the hospitals are } \\
\text { located }\end{array}$ & -4 & -5 \\
\hline & $\begin{array}{l}\text { The possibility of unexpected events in the city where the } \\
\text { hospitals are located }\end{array}$ & -4 & -3 \\
\hline & $\begin{array}{l}\text { Greater possibility of man-made disasters in the city where } \\
\text { the hospitals are located }\end{array}$ & -3 & -3 \\
\hline
\end{tabular}




\begin{tabular}{|c|c|c|c|}
\hline Aspects & Factors & Influence & Certainty \\
\hline & Population Positive attitude toward green energy & +3 & +3 \\
\hline & $\begin{array}{l}\text { Population Positive attitude toward green and organic } \\
\text { products }\end{array}$ & +3 & +3 \\
\hline \multirow[t]{6}{*}{ Legal } & Lack of legal clarity for hospitals activities development & -4 & -4 \\
\hline & Tax and employment laws ratified by the government & -4 & -4 \\
\hline & $\begin{array}{l}\text { Inappropriate budgeting system for hospitals (general } \\
\text { budget, linear budget, ownership of the remaining budget } \\
\text { resulting from frugality) }\end{array}$ & -5 & -4 \\
\hline & $\begin{array}{l}\text { Deficiency in health technologies evaluation (import } \\
\text { permits for high-end technologies and expensive drugs) }\end{array}$ & -4 & -5 \\
\hline & $\begin{array}{l}\text { Poor supportive laws for attracting domestic and } \\
\text { international investors in manufacture, equipment, and } \\
\text { renovation of hospitals (including bank laws, facilities, } \\
\text { loans, letters of guarantee) }\end{array}$ & -3 & -5 \\
\hline & $\begin{array}{l}\text { The requirement for hospitals to observe scientific and } \\
\text { local guidelines approved by the Ministry of Health and } \\
\text { insurance companies }\end{array}$ & +5 & +2 \\
\hline
\end{tabular}

Table 2.

\section{Discussion}

Findings indicated that the micro environment factors of public hospitals affected quality of services as well as the expenditures. One of the factors at the micro level was lengthy waiting time, particularly, in emergency rooms (20-23).

The macro environment factors affect hospitals in two ways: First, factors with direct influence, such as higher fertility rates, hospital services tariffs, changes in the patterns of diseases, and hospital budgeting. Second, factors with indirect affect, such as stakeholders, distributors, economic sanctions, government corruption, centralization and high bank interest rates. As health and illness are considered social phenomena (24) moving toward more aging population as the senile will make up $20 \%$ of the Iranian population by 2050 (25). This indicates changing the disease patterns (26) relying on updated technologies to enhance the self-efficacy/self-control and increasing the community-based services, and involving patients and their carer, in decision making about their health and the services (27).

Other interconnected social determinants of health are related to unhealthy lifestyle behaviors, poverty, outskirts/assembly residential, drug abuse/addiction, lack of physical activities, which can result in more chronic illnesses and threatening public hospitals and their care provision to individuals. (28). 
From the economic point of view, public investments in the health system had not increased in proportion to the increased health costs $(29-31)$. One of the main issues that hospitals are confronted is the payment system (fee for services), which is designed to encourage service providers to offer more services (32). Regarding the mega trend of change from volume-based to value-based paradigm (28) One of the innovative method of value-based system is strategic service purchase or service package $(43,45)$

Implementation of the Health Transformation Plan (HTP) is also a good strategy to decrease the Out-ofPocket (OOP) payments for inpatient services and eradicated informal payments to physician. Furthermore, delegation of some costly parts of hospitals to private partners based on the "publicprivate- partnership" models can be a beneficial solution for enhancing the harmony between Iranian health policies and change of paradigm from volume to value (33).

This review also highlighted that with healthcare technological advances like home care, remote medicine, remote training, and electronic medical record and smart hospitals, technology had great impacts on the performance of hospitals. Therefore, it is recommended that with rapid changes in technology, directors of public hospitals pay attention to such changes and consider localizing technology and applying the Health Technology Assessments (HTA) to enhance the appropriate usage of health technologies based on the needs of patients and general population.

\section{Conclusion}

The evidence recommended some key reforms in Iranian hospitals and the healthcare system as a whole to improve the quality and at the same time efficiency of services. First, it is required to revise the current referral system into a more sustainable one. This can result in more cost-efficiency of services as well as result in more equitable healthcare system, as the budget can be used differently for those who need it more (e.g. remote/rural areas). Secondly, small public hospitals may not survive considering the current threats, however small hospitals can be integrated to provide a more holistic system. This can result in chain hospitals meantime we should consider the blind spots of large hospitals such as bureaucratic system and financial abuse in regards to advertising and investing on pharmaceutical and medical instruments in large scale. Third, there can be more focus on using the modern technology, particularly for chronic illnesses. However, this needs to happen using appropriate technology assessment process to prevent over usage of technologies and financial burden. Fourth, shifting the hospitals and health care system into more community-based services and considering the health more holistically.

\section{Limitations}

The results of this research are a cross-sectional view of the changing health system in Iran and as the "Environmental scanning" is a dynamic method it should be updated every 3-4 years to match the everchanging situation.

\section{Declarations}




\section{Acknowledgements}

This research, derived from proposal No. 95-01-07-13769, was conducted by Dr. Kimia Pourmohammadi as part of the activities required for a PhD degree in health services management at the Shiraz University of Medical Sciences. The authors wish to express their sincere gratitude to the research administration of Shiraz University of Medical Sciences for its administrative support.

\section{*Authors' contributions}

PB designed the study and its overall methodology; KP finalized the data synthesis and the article itself. and searched all the databases, retrieved the sources and prepared the initial draft of the article. PS contributed to data analysis and edited the article. AS improving the structure, conclusion and English edition of the paper. The study was supervised by $\mathrm{NH}$. All authors read and approved the final manuscript.

\section{*Funding}

This research was funded by Shiraz University of Medical Sciences, Shiraz, Iran. This fund was only allocated to the study for covering data collection and purchasing the software of data analysis. The university (as a funding institute) did not have any other role in the design of the study nor data analysis, interpretation of data and writing the manuscript.

\section{*Availability of data and material}

Data is available in an endnote library.

\section{*Ethics approval and consent to participate}

This study is approved by Shiraz University of Medical Sciences ethics committee with the ID number of IR.SUMS.REC.1396.S274.

\section{*Consent for publication}

There was no difficulty in publishing the results. All the included databases and materials are available for public use.

\section{*Competing interests}

Authors declare that there is no conflict of interest.

\section{References}

1. Team FME. PESTLE Analysis. Strategy Skills. Free management ebooks. 2013:15.

2. Amuna YMA, Al Shobaki MJ, Naser SSA. Strategic Environmental Scanning: an Approach for Crises Management. International Journal of Information Technology and Electrical Engineering. 
2017;6(3):28-34.

3. Rajabi F, Esmailzadeh H, Rostamigooran N, Majdzadeh R, Doshmangir L. Future of health care delivery in iran, opportunities and threats. Iranian journal of public health. 2013;42(Supple1):23.

4. Bonu S, Gutierrez LC, Borghis A, Roche FC. Transformational trends confounding the South Asian health systems. Health policy. 2009;90(2):230-8.

5. World Health 0 . How can hospital performance be measured and monitored? How can hospital performance be measured and monitored?2003. p. 17-.

6. Masoumpour SM, Rahimi SH, Kharazmi E, Kavousi Z, Mosalah NH, Abedi Z. Assessing waiting time in emergency department of Shahid Faghihi hospital, Shiraz and presenting appropriate strategies using quality function deployment (QFD) method, 2011-2012. Hakim Research Journal. 2013;16(2):159-68.

7. Pourmohammadi K, Hatam N, Shojaei P, Bastani P. A comprehensive map of the evidence on the performance evaluation indicators of public hospitals: a scoping study and best fit framework synthesis. Cost Effectiveness and Resource Allocation. 2018;16(1):64.

8. Zarchi MR, Jabbari A, Rahimi SH, Shafaghat T, Abbasi S. Preparation and designing a checklist for health care marketing mix, with medical tourism approach. Int J Travel Med Glob Health. 2013;1:1038.

9. Bastani P, Vatankhah S, Salehi M. Performance ratio analysis: A national study on Iranian hospitals affiliated to ministry of Health and Medical Education. Iranian journal of public health. 2013;42(8):876.

10. Hatam N, Pourmohammadi K, Keshtkaran A, Javanbakht M, Askarian M. Factors affecting efficiency of social security hospitals in Iran: Data Envelopment Analysis. HealthMED. 2012;6(6):1961-8.

11. Pourmohammadi K, Hatam N, Bastani P, Lotfi F. Estimating production function: a tool for Hospital Resource Management. Shiraz E-Medical Journal. 2014;15(4):e23068.

12. Shadpour K. Health sector reform in Islamic Republic of Iran. Hakim Research Journal. 2006;9(3):118.

13. Davis MA, Miles G, McDowell WC. Environmental scanning as a moderator of strategy-performance relationships: an empirical analysis of physical therapy facilities. Health services management research. 2008;21(2):81-92.

14. Zhang X, Majid S, Foo S. The contribution of environmental scanning to organizational performance. Singapore Journal of Library \& Information Management. 2011;40(1):65-88.

15. Fabbe-Costes N, Roussat C, Taylor M, Taylor A. Sustainable supply chains: a framework for environmental scanning practices. International Journal of Operations \& Production Management. 2014;34(5):664-94.

16. Lesca N, Caron-Fasan M-L, Falcy S. How managers interpret scanning information. Information \& Management. 2012;49(2):126-34. 
17. Zarchi MKR, Jabbari A, Hatam N, Bastani P, Shafaghat T, Fazelzadeh O. Strategic Analysis of Shiraz Medical Tourism Industry: A Mixed Method Study. Galen Medical Journal. 2018;7:e1021.

18. West DC, Ford J, Ibrahim EX. Strategic marketing: creating competitive advantage: Oxford University Press, USA; 2015.

19. Srivastava A, Thomson SB. Framework analysis: a qualitative methodology for applied policy research. Journal of Administration \& Governance. 2009;4(2):72-9.

20. Hashemi SMEF, Asiabar AS, Rezapour A, Azami-Aghdash S, Amnab HH, Mirabedini SA. Patient waiting time in hospital emergency departments of Iran: A systematic review and meta-analysis. Medical journal of the Islamic Republic of Iran. 2017;31:79.

21. Helbig M, Helbig S, Kahla-Witzsch HA, May A. Quality management: reduction of waiting time and efficiency enhancement in an ENT-university outpatients' department. BMC health services research. 2009;9(1):21.

22. Bahrami MA, Rafiei S, Abedi M, Askari R. Data envelopment analysis for estimating efficiency of intensive care units: a case study in Iran. International journal of health care quality assurance. 2018;31(4):276-82.

23. Rahimi H, Bahmaei J, Shojaei P, Kavosi Z, Khavasi M. Developing a Strategy Map to Improve Public Hospitals Performance with Balanced Scorecard and DEMATEL Approach. Shiraz E-Med J. 2018;19(7):e64056.

24. Barati O, Keshtkaran A, Ahmadi B, Hatam N, Khammarnia M, Siavashi E. EQUITY IN THE HEALTH SYSTEM: AN OVERVIEW ON NATIONAL DEVELOPMENT PLANS. Sadra Med Sci J 2015;3(1):77-88.

25. Roudi F, Azadi P, Mesgaran M. Iran's Population Dynamics and Demographic Window of Opportunity, working paper 4, stanford iran 2040 project. stanford University. 2017:1-29.

26. Nabipour I. Megatrend analaysis of the health policies of IR Iran. Tibb-i junūb. 2014;17(5):1007-30.

27. Popkin BM, Adair LS, Ng SW. Global nutrition transition and the pandemic of obesity in developing countries. Nutrition reviews. 2012;70(1):3-21.

28. Bahadoran Z, Mirmiran P, Hosseini-Esfahani F, Azizi F. Fast food consumption and the risk of metabolic syndrome after 3-years of follow-up: Tehran Lipid and Glucose Study. European journal of clinical nutrition. 2013;67(12):1303-9.

29. Hammarström A, Janlert U. Early unemployment can contribute to adult health problems: results from a longitudinal study of school leavers. Journal of Epidemiology \& Community Health. 2002;56(8):624-30.

30. Kroll LE, Lampert T. Unemployment, social support and health problems: results of the GEDA study in Germany, 2009. Deutsches Ärzteblatt International. 2011;108(4):47.

31. Schmitz $\mathrm{H}$. Why are the unemployed in worse health? The causal effect of unemployment on health. Labour Economics. 2011;18(1):71-8.

32. Ginsburg PB. Fee-for-service will remain a feature of major payment reforms, requiring more changes in Medicare physician payment. Health Affairs. 2012;31(9):1977-83. 
33. Piroozi B, Rashidian A, Moradi G, Takian A, Ghasri H, Ghadimi T. Out-of-pocket and informal payment before and after the health transformation plan in Iran: evidence from hospitals located in Kurdistan, Iran. International journal of health policy and management. 2017;6(10):573. 